\title{
MONITORING OF ACTUAL STATUS AND DEVELOPMENT OF ACTIVE ALUMINIUM IN SOILS IN SLOVAKIA
}

\author{
JARMILA MAKOVNÍKOVÁ*, JOZEF KOBZA
}

Soil Science and Conservation Research Institute Bratislava

MAKOVNÍKOVÁ, J. - KOBZA, J.: Monitoring of actual status and development of active aluminium in soils in Slovakia. Agriculture (Pol’nohospodárstvo), vol. 59, 2013, no. 4, pp. 178-184.

Active aluminium contents in agricultural soils of Slovakia were evaluated in the frame of partial-monitoring system - soil. The soil samples were taken in 5 years regular intervals from depths of $0-0.10$ and $0.35-0.45 \mathrm{~m}$. In the dry homogenised samples, soil reaction ( $\mathrm{pH}$ in $\mathrm{CaCl}_{2}$ ), exchangeable cation $\mathrm{Ca}^{2+}$ and active $\mathrm{Al}$ content by Sokolov (soil is extracted with $1 \mathrm{~N} \mathrm{KCl}$ and $\mathrm{Al}$ is precipitated with $\mathrm{NaF}$ ) in the samples with $\mathrm{pH}$ value lower than 6.0 were measured. Active Al content was in the range $0.10-684.0 \mathrm{mg} / \mathrm{kg}$ with the average value $59.28 \mathrm{mg} / \mathrm{kg}$ and median value 8.30 $\mathrm{mg} / \mathrm{kg}$ in the depth $0-0.10 \mathrm{~m}$. In the depth $0.35-0.45 \mathrm{~m}$, the average value was $59.30 \mathrm{mg} / \mathrm{kg}$ and the median value was $9.00 \mathrm{mg} / \mathrm{kg}$. Significant differences in average and median values between the arable land and permanent grassland are determined as a consequence of the relationship between soil quality and its use. The increase in the active aluminium content (between first and last monitoring cycles) was determined in the group Podzols, Lithic Leptosols used as the permanent grassland as well as in the group Cambisols on the crystalline rocks and in the group Fluvisols used as arable land.

Key words: active aluminium content, acidification, soil degradation

Aluminium (Al) is the third most abundant element in the earth crust (Hiradate 2004) as well as a major element in soils. Al total content in soils is depended on the primary and secondary minerals content and it ranged in Slovakian soils from $0.76 \%$ to $14.48 \%$ in A-horizon and from $0.22 \%$ to $13.88 \%$ in C-horizon (Čurlík \& Šefč́́k 1999). It is not an essential element, and its impacts on live organisms including man are highly toxic (Horák et al. 1995; Kozák \& Borůvka 1998). Al toxicity to plants manifests in low acidic and acidic soils. High Al concentrations such as $\mathrm{Al}^{3+}$ represent an important growth and yield-limiting factor for crops in acidic soils ( $\mathrm{pH} \leq 5.5$; Makovníková \& Kanianska 1996a; Mačuha 1999; Kanianska 2000; Meriño-Gergichevich 2010). Al toxicity results in alterations of the physiological and biochemical processes of plants and consequently their productivity. The decrease in root growth is one of the initial and most evident symptoms of Al toxicity at micromolar concentrations in plants (Rincón-Zachary 2010), inducing reduced capacity for water and nutrient uptake. It may possibly penetrate plant-root cells, and under certain conditions may be translocated within the plant body in at least four different forms (simple ions, more complex colloidal electrolytes, co-ordinated complex anions and organic compound). Phosphorus uptake is inhibited in plants, as well as growth and branching of root hairs; it negatively affects the ability of the plants for the uptake of $\mathrm{Ca}, \mathrm{Mg}, \mathrm{Mn}$ and $\mathrm{Zn} . \mathrm{Al}$ is one of the major limiting factors for root growth in acidic subsoil. Al is present in soils in a variety of forms and bound to the soil constitutents, particularly onto clay particles and organic matter independent from environmental conditions. Al phytotoxicity depends on its chemical forms. Many

RNDr. Jarmila Makovníková, PhD. (*Corresponding author), Prof. Ing. Jozef Kobza, CSc., Soil Science and Conservation Research Institute Bratislava, Regional Station Banská Bystrica, 97404 Banská Bystrica, Mládežnícka 36, Slovak Republic. E-mail: j.makovnikova@vupop.sk 
authors reported that only mobile and exchangeable forms of Al play a significant role in Al toxicity (Mačuha 1999; Hiradate 2004; Makovníková 2005; Meriño-Gergichevich 2010). The solubility of Al increases with the decrease in the soil reaction (Makovníková \& Kanianska 1996b; Hiradate 2004; Mrvic et al. 2007; Meriño-Gergichevich 2010). Till the boundary $\mathrm{pH}$ in $\mathrm{CaCl}_{2}=6$, the dominant $\mathrm{Al}$ forms in soil solution are aqua-hydroxo-Al complexes; these include monomeric $\mathrm{Al}$ ions forming complexes with $\mathrm{OH}$ and/or $\mathrm{OH}_{2}$ groups, such as $\mathrm{Al}\left(\mathrm{H}_{2} \mathrm{O}\right)_{6}{ }^{3+}$, $\mathrm{Al}\left(\mathrm{H}_{2} \mathrm{O}\right)_{5}(\mathrm{OH})^{2+}$ and $\mathrm{Al}\left(\mathrm{H}_{2} \mathrm{O}\right)_{4}(\mathrm{OH})^{+}$(Hiradate 2004; Meriño-Gergichevich 2010). The Al monomeric ions are less phytotoxic than $\mathrm{Al}_{13}$, but more phytotoxic than Al-organic acid complexes as published by Hiradate (2004). The toxic form is cation $\mathrm{Al}^{3+}$; phytotoxicity, however, also shows ions $\mathrm{Al}(\mathrm{OH})^{2+}$, or $\mathrm{Al}(\mathrm{OH})_{2}^{+}$, with them $\mathrm{Al}^{3+}$ ions are equally present in soil solution (Hue 1986). Most of the Al in soil solution is in the form of compounds with organic substances, whereby the capability of organic ligands to decrease $\mathrm{Al}$ phytotoxicity depends on the stability of the complexes (Mládková et al. 2004; Makovníková 2005). With increasing $\mathrm{pH}$ value, $\mathrm{Al}$ ions are changed to insoluble aluminium hydroxide. Al substances are also dissolved in strong alkaline soil reaction and they form negatively loaded tetrahydroxy aluminium ions (Hue 1986).

The active $\mathrm{Al}$ content in context with soil reaction is monitored in partial monitoring system - soil - from 1993 year in 5-year cycles in basic monitoring network and yearly in key localities network. The aim of this work was to evaluate the distribution of active $\mathrm{Al}$ in the last sampling cycle as well as to compare the active aluminium content determined in all the sampling cycles.

\section{MATERIAL AND METHODS}

Status and development of active $\mathrm{Al}$ contents in agricultural soils of Slovakia was evaluated in the frame of partial monitoring system - soil (CMS-P), created by basic monitoring network and key monitoring sites (Kobza et al. 2009). Monitoring network of CMS-P is created on the basis of ecological principle (polluted as well as unpolluted regions) and represents all the most frequent soil types and sub- types in Slovakia climate regions. Soil samples were collected from the depths of $0-0.10$ and $0.35-0.45 \mathrm{~m}$ from agricultural soils (arable land and permanent grassland) in 5-year repetitions (in 1993, 1997, 2002 and 2007 years). Samples were air-dried and passed through $0.002 \mathrm{~m}$ sieves. In the samples, soil reaction (exchangeable $\mathrm{pH}$ in $\mathrm{CaCl}_{2}$ potentiometrically (Kolektív 2011)), exchangeable cation $\mathrm{Ca}^{2+}$ and active Al content by Sokolov (soil is extracted with $1 \mathrm{~N}$ $\mathrm{KCl}$ and $\mathrm{Al}$ is precipitated with $\mathrm{NaF}$ ) in the samples with $\mathrm{pH}$ value lower than 6.0 (Kolektív 2011)) were measured (115 samples, 62 samples from arable land and 53 samples from permanent grassland). All the methods (soil sampling, chemical and physical procedures) used are described in more detail in the publication unified working methods of soil analysis (Kolektív 2011).

Statistical analysis and evaluation of the results were carried out using the program Statgraphics XV Centurion.

\section{RESULTS AND DISCUSSION}

ActiveAlcontentwasin therange $0.10-684.0 \mathrm{mg} / \mathrm{kg}$ with an average value of $59.28 \mathrm{mg} / \mathrm{kg}$ and median value of $8.30 \mathrm{mg} / \mathrm{kg}$ in the depth $0-0.10 \mathrm{~m}$ (Figure 1 - Al status in the year 2007).

Similar values of active Al content were measured in the depth $0.35-0.45 \mathrm{~m}$, the average value was $59.30 \mathrm{mg} / \mathrm{kg}$ and the median value was 9.00 $\mathrm{mg} / \mathrm{kg}$. High differences between average and median values suggest an abnormal statistical distribution of this parameter. Table 1 shows the statistical distribution of active aluminium content in arable lands and permanent grasslands (actual status in the last sampling cycle -2007 year).

Significant difference in average and median values between the arable lands and permanent grasslands is a consequence of the relationship between soil quality and its use. On the one hand, it is influenced by the parent substrate, its acidity or alkalinity; on the other hand, especially in the depth of $0-0.10 \mathrm{~m}$ the influence of anthropogenic factors such as tillage, fertiliser application, the impact of the emission components of the atmosphere and land utilities is also included. Attention must be given to 
high maximum values of active aluminium on arable land, which can significantly inhibit the growth of cultivated crops and subsequently contaminate the nutrient chain.

Negative correlation between active $\mathrm{Al}$ content and soil reaction values and between active $\mathrm{Al}$ content and exchangeable $\mathrm{Ca}^{2+}$ cation content in soil (Table 2) is consistent with the work of various authors (Makovníková \& Kanianska 1996b; Makovníková 2002; Hiradate 2004; Kobza et al. 2009; Meriño-Gergichevich 2010) and highlights the potential danger of acidification. Mrvic et al. (2007) reported similar coefficient of correlation between $\mathrm{pH}$ value and active $\mathrm{Al}$ content $(r=-0.65)$ for Stagnosols in Serbia, whereas Mládková et al. (2004) determined a slightly lower coefficient for grassland in the Jizera Mountains region in the Czech Republic. Active $\mathrm{Al}$ content is maximally affected by the parameters of soil acidity, and investigation of other parameters (humus content, fine sand and clay content) show only weak correlation (Mrvic et al. 2007).

Active Al content's statistical distribution within profiles of CMS-P according to soil representatives' groups [according to WRB (The World Reference Base for Soil Resources) 2006] in context with $\mathrm{pH}$ values and $\mathrm{Al}^{3+} / \mathrm{Ca}^{2+}$ ratio is presented in Table 3 (actual status in the last sampling cycle -2007 year).

The measured average value of active $\mathrm{Al}$ content was from $3.43 \mathrm{mg} / \mathrm{kg}$ (Stagnosols used as arable land) to $455.57 \mathrm{mg} / \mathrm{kg}$ (group Podzols, Lithic Leptosols used as permanent grassland) in the depth $0-0.10 \mathrm{~m}$. The higher total content of $\mathrm{Al}$ in soils developed on the crystalline rocks in comparison to the soil developed on the flysch as published by Čulík \& Šefčík (1999) is not reflected in active Al content, which

T

Statistical distribution of active Al in arable lands and permanent grasslands

\begin{tabular}{|l|c|c|c|c|c|c|c|c|}
\hline \multirow{3}{*}{$\begin{array}{l}\text { Depth } \\
{[\mathrm{m}]}\end{array}$} & \multicolumn{9}{|c|}{ Active Al $[\mathrm{mg} / \mathrm{kg}]$} \\
\cline { 2 - 9 } & \multicolumn{3}{|c|}{ Arable land } & \multicolumn{5}{c|}{ Permanent grassland } \\
\cline { 2 - 9 } & Average & Median & Min & Max & Average & Median & Min & Max \\
\hline $0-0.10$ & 14.04 & 7.70 & 0.10 & 195.30 & 109.97 & 25.60 & 0.10 & 684.00 \\
$0.35-0.45$ & 28.40 & 2.70 & 0.10 & 488.00 & 77.78 & 18.30 & 0.10 & 470.00 \\
\hline
\end{tabular}

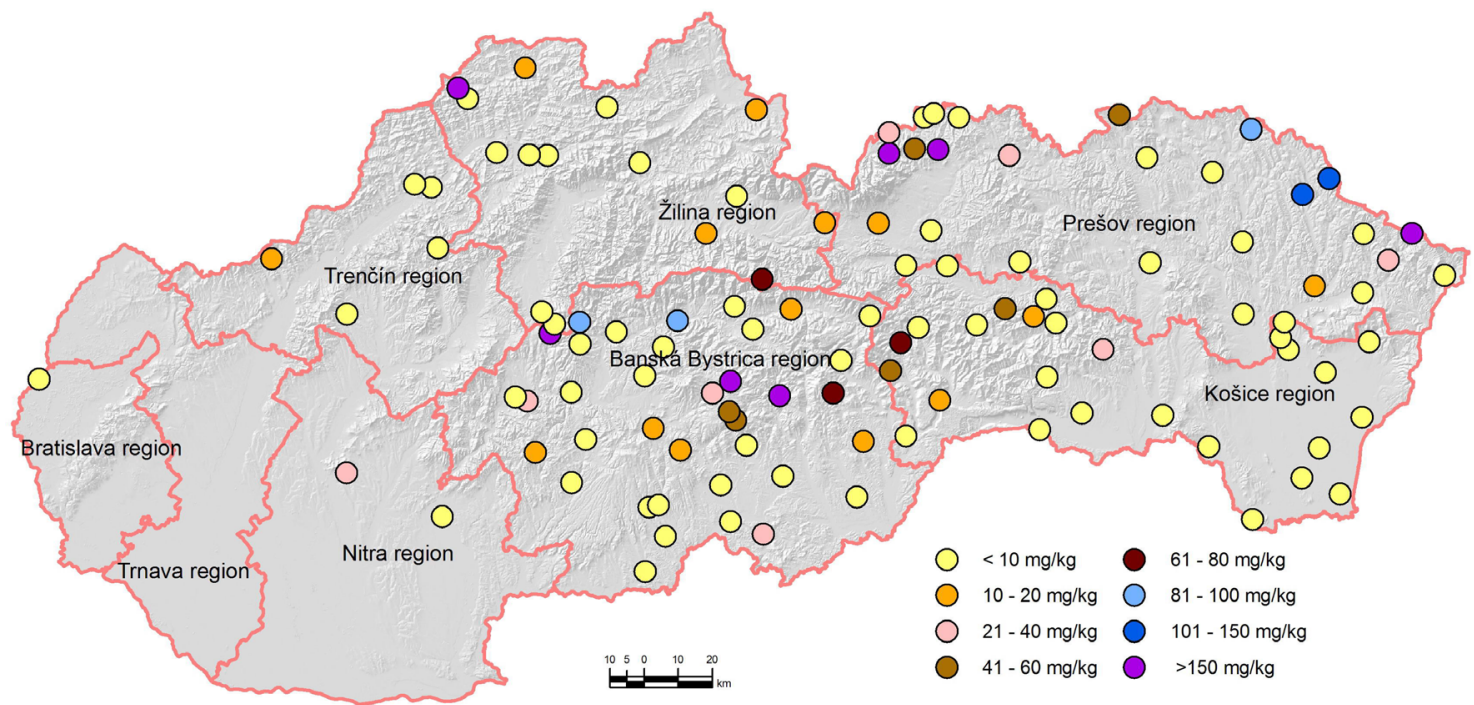

Figure 1. Active aluminium content (status in the last sampling cycle) 
is conditioned not only by $\mathrm{Al}$ total content but also by soil reaction. The high differences between average and median values are caused by outlying high values in the evaluated soil groups. The higher content of active aluminium in the subsoil in the case of Cambisols on the acidic crystalline rocks and Stagnosols used as arable land (as indicated by the median) may result in depression root penetration depth as well as in reducing the depth of the root system and thereby increasing water deficit in subsequent crops. Exchangeable cation $\mathrm{Ca}^{2+}$ plays a fundamental role in the $\mathrm{Al}$ toxicity through $\mathrm{Al}-\mathrm{Ca}$ interactions improving physiological and biochemical processes in plants, and it is a useful amendment for correcting Al negative effects on crops growing in acidic soils. It has also been recognised that the ratio of equivalent amounts of cations $\mathrm{Al}^{3+} / \mathrm{Ca}^{2+}$ (Grishina \& Baranova 1990; Meriño-Gergichevich 2010) is a good indicator of $\mathrm{Al}$ stress in nutrient solutions and may be used to predict acidity effect on plant growth and development. Grishina and Baranova (1990) reported that there is a $50 \%$ risk of negative effect on sensitive crops when the $\mathrm{Al}^{3+} / \mathrm{Ca}^{2+}$ ratio in soil is greater than 0.50 and greater than 1.00 for the less sensitive

$\mathrm{T}$ a

Spearman correlation analysis

\begin{tabular}{|l|c|c|c|c|c|c|}
\hline \multirow{2}{*}{} & \multicolumn{5}{|c|}{ Spearman correlation coefficient } \\
\cline { 2 - 7 } & \multicolumn{3}{|c|}{ Arable land } & \multicolumn{2}{c|}{ Permanent grassland } \\
\cline { 2 - 7 } & Active Al & $\mathrm{pH}$ & $\mathrm{Ca}^{2+}$ & Active Al & $\mathrm{pH}$ & $\mathrm{Ca}^{2+}$ \\
\hline Active Al $[\mathrm{mg} / \mathrm{kg}]$ & 1 & $-0.77^{++}$ & $-0.58^{++}$ & 1 & $-0.66^{++}$ & $-0.55^{++}$ \\
$\mathrm{pH}$ & & 1 & $0.57^{++}$ & & 1 & $0.52^{++}$ \\
$\mathrm{Ca}^{2+}[\mathrm{cmol} / \mathrm{kg}]$ & & & 1 & & & 1 \\
\hline
\end{tabular}

${ }^{++}$Statistically significant at the level $\alpha=0.05$

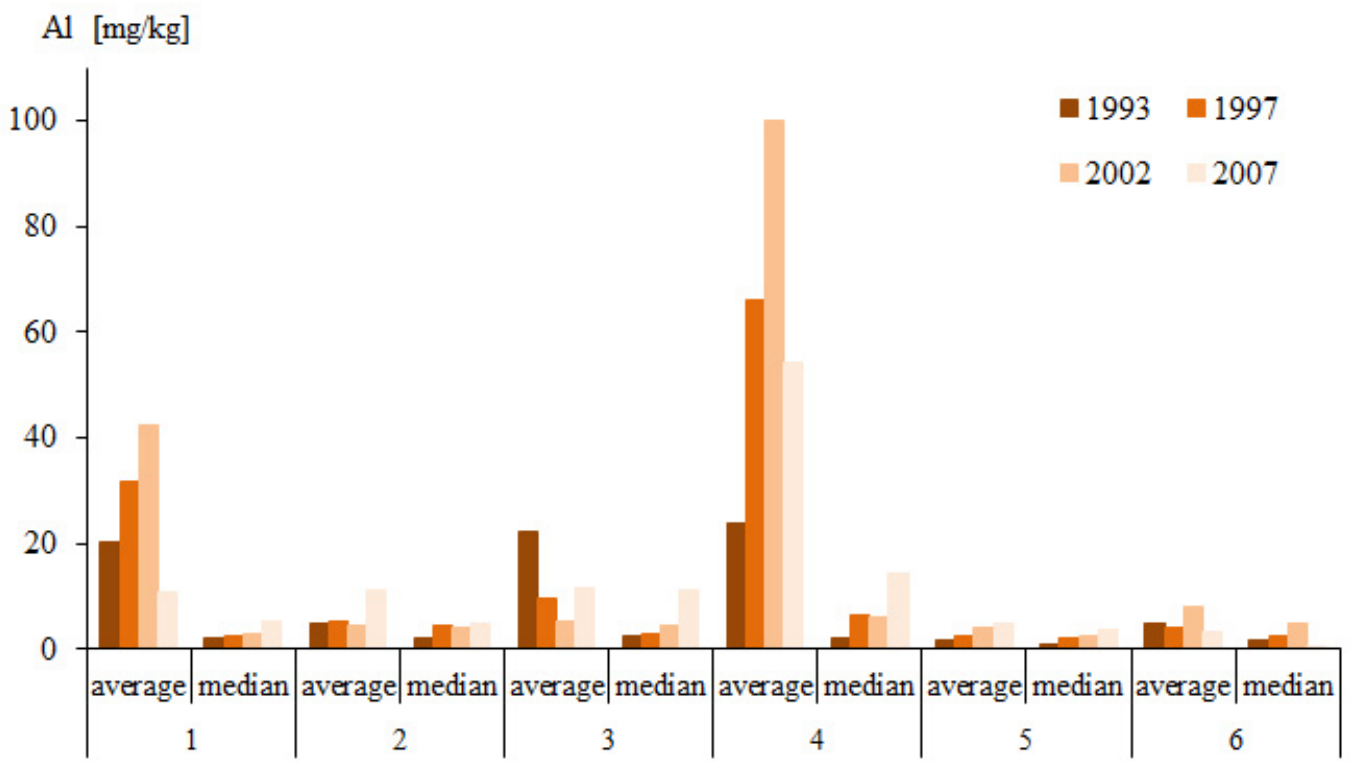

Explanatory notes: 1 - Cambisols on the flysch, 2 - Cambisols on the crystalline rocks, 3 - Luvisols, 4 - Fluvisols, 5 - Mollic Fluvisols, 6 - Stagnosols

Figure 2. Active aluminium content in soil groups used as grassland (1993, 1997, 2002 and 2007 year) in the depth $0-0.10 \mathrm{~m}$ 
crops (Grishina \& Baranova 1990). The $\mathrm{Al}^{3+} / \mathrm{Ca}^{2+}$ ratio greater than 1.00 , which is the important growth and yield-limiting factor for crops, was determined in the groups of soils used as arable land (Cambisols on the crystalline rocks and Cambisols on the flysch and Fluvisols). The influence of exchangeable $\mathrm{Ca}$ on active $\mathrm{Al}$ content was also confirmed by Mládková et.al (2004).

The comparison of active Al content (average and median values) determined in the sampling cycles in arable land and permanent grassland groups is shown in Figures 2 and 3.

The apparent increase in the active aluminium content (between first and last monitoring cycles) was measured in the group Podzols, Lithic Leptosols used as permanent grassland as well as in the group Cambisols on the crystalline rocks and Fluvisols used as arable land. These results are consistent with the $\mathrm{pH}$ value trends during the observed period (Makovníková \& Dodok 2012). Comparison of the third and fourth cycle shows a decrease in the active aluminium content in the group Podzols, Lithic Leptosols used as permanent grassland as well as in the case of Fluvisols used as arable land. The average active Al content decreased in the group Podzols, Lithic Leptosols used as permanent grassland and in the groups Cambisols on the flysch and Fluvisols used as arable land. Negative trends, increase in median value, were observed in the case of Cambisols on the flysch, Luvisols and Fluvisols used as arable land.

T a b 1 e 3

Statistical distribution of active aluminium content in soil representative groups (in the last sampling cycle)

\begin{tabular}{|c|c|c|c|c|c|c|c|}
\hline \multirow[b]{2}{*}{ Soil representative group } & \multicolumn{7}{|c|}{ Active $\mathrm{Al}[\mathrm{mg} / \mathrm{kg}]$} \\
\hline & Depth $[\mathrm{m}]$ & Average & Median & Min & Max & $\begin{array}{l}\mathrm{pH} \text { in } \\
\mathrm{CaCl}_{2}\end{array}$ & $\mathrm{Al}^{3+} / \mathrm{Ca}^{2+}$ \\
\hline \multirow{2}{*}{ Podzols, Lithic Leptosols - PG } & $0-0.10$ & 455.57 & 482.00 & 295.00 & 684.00 & 3.38 & 38.73 \\
\hline & $0.35-0.45$ & 159.00 & 138.00 & 120.00 & 259.00 & 4.20 & - \\
\hline \multirow{2}{*}{ Cambisols on the crystalline rocks - PG } & $0-0.10$ & 38.46 & 19.40 & 2.70 & 182.00 & 4.68 & 12.31 \\
\hline & $0.35-0.45$ & 61.97 & 16.70 & 0.45 & 357.00 & 4.82 & - \\
\hline \multirow{2}{*}{ Cambisols on the crystalline rocks - AL } & $0-0.10$ & 11.27 & 4.95 & 0.10 & 49.50 & 5.66 & 3.01 \\
\hline & $0.35-0.45$ & 24.90 & 13.50 & 0.10 & 72.90 & 5.55 & - \\
\hline \multirow{2}{*}{ Cambisols on the flysch - PG } & $0-0.10$ & 87.28 & 30.95 & 0.45 & 308.00 & 4.91 & 25.99 \\
\hline & $0.35-0.45$ & 115.71 & 18.30 & 0.27 & 470.00 & 5.18 & - \\
\hline \multirow{2}{*}{ Cambisols on the flysch $-\mathrm{AL}$} & $0-0.10$ & 10.67 & 5.35 & 0.45 & 41.90 & 5.87 & 2.10 \\
\hline & $0.35-0.45$ & 4.10 & 2.47 & 0.45 & 9.49 & 6.05 & - \\
\hline \multirow{2}{*}{ Stagnosols - PG } & $0-0.10$ & 12.52 & 13.00 & 3.60 & 30.60 & 5.41 & 0.92 \\
\hline & $0.35-0.45$ & 36.30 & 14.45 & 0,10 & 194.00 & 5.28 & - \\
\hline \multirow{2}{*}{ Stagnosols - AL } & $0-0.10$ & 3.43 & 0.45 & 0.10 & 14.40 & 5.71 & 0.33 \\
\hline & $0.35-0.45$ & 38.71 & 0.67 & 0.10 & 418.00 & 5.66 & - \\
\hline \multirow{2}{*}{ Fluvisols - AL } & $0-0.10$ & 54.34 & 14.40 & 4.77 & 195.00 & 5.64 & 5.13 \\
\hline & $0.35-0.45$ & 60.45 & 9.79 & 0.45 & 179.00 & 5.95 & - \\
\hline \multirow{2}{*}{ Luvisols - AL } & $0-0.10$ & 11.67 & 11.10 & 0.10 & 28.40 & 6.20 & 0.63 \\
\hline & $0.35-0.45$ & 63.02 & 4.50 & 0.10 & 488.00 & 6.20 & - \\
\hline \multirow{2}{*}{ Mollic Fluvisols - AL } & $0-0.10$ & 4.86 & 3.82 & 0.10 & 11.70 & 5.99 & 0.26 \\
\hline & $0.35-0.45$ & 22.38 & 4.50 & 0.10 & 66.60 & 6.08 & - \\
\hline
\end{tabular}

$\mathrm{AL}$ - arable land; $\mathrm{PG}$ - permanent grassland 


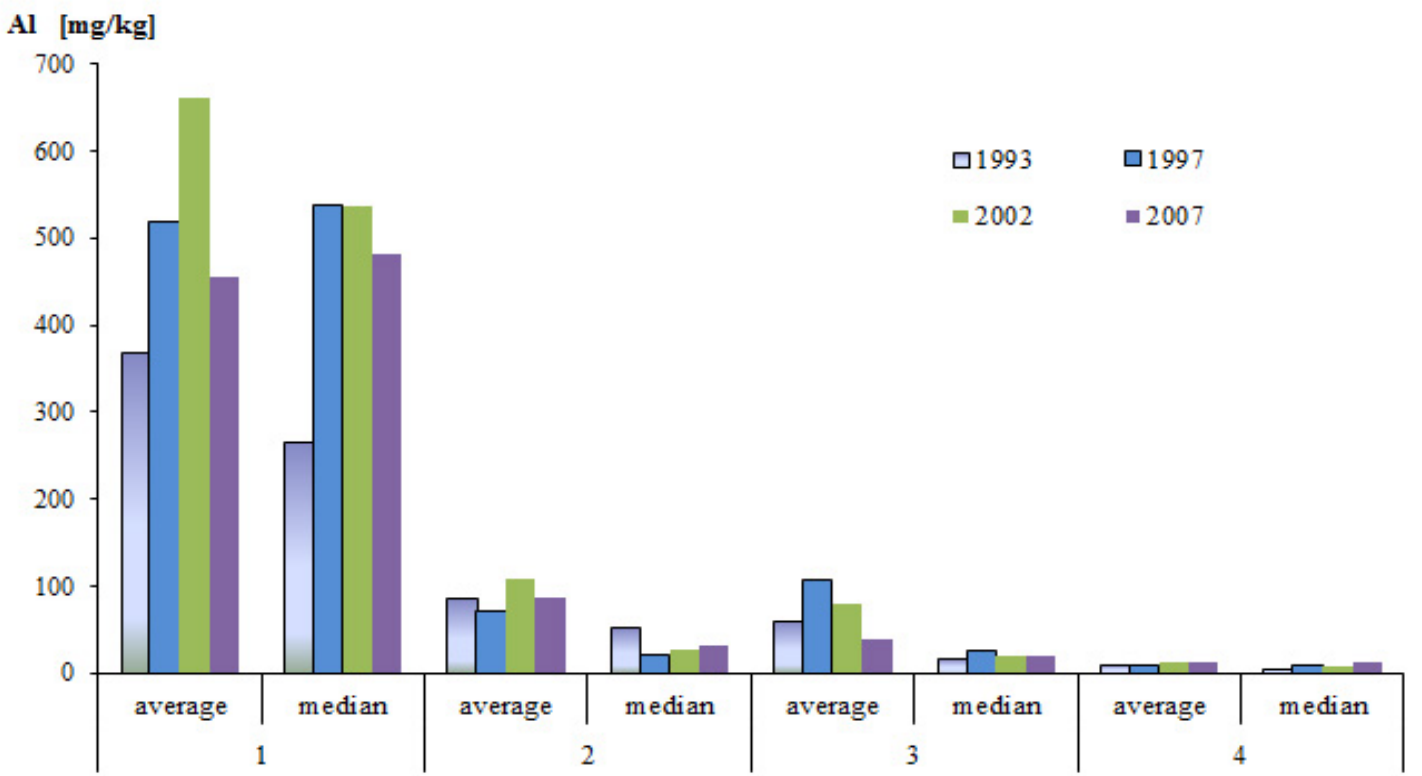

Explanatory notes: 1 - Podzols and Lithic Leptosols, 2 - Cambisols on the flysch, 3 - Cambisols on the crystalline rocks, 4 - Stagnosols

Figure 3. Active aluminium content in soil groups used as grassland (1993, 1997, 2002 and 2007 year) in the depth $0-0.10 \mathrm{~m}$

\section{CONCLUSIONS}

The status of active aluminium content in the last monitoring cycle in agricultural soils of SR was significantly lower in the arable land compared with permanent grassland, which is a consequence of the relationship between soil quality and its use. Attention must be given to high maximum values of active aluminium on arable land, which can significantly inhibit the growth of the cultivated crops. In one of the four evaluated soil groups used as permanent grassland, the median value increased in the last sampling cycle compared with first sapling cycle. On the other hand, in the case of arable land, the median values of active $\mathrm{Al}$ content increased in all the evaluated soil groups. It is necessary in the future to pay attention to the arable land with the values of soil reaction in weak acid and the acidic range as well as with a lower quantity and quality of soil organic matter. To overcome the limitations of $\mathrm{Al}$ phytotoxicity, $\mathrm{Ca}$ amendments are an agronomic practice commonly used to reduce the acidic effect on plant growth and development.

\section{REFERENCES}

ČURLÍK, J. - ŠEFČÍK, P. 1999. Geochemický atlas SR [Geochemical atlas]. Pôdy. Bratislava : VÚPOP Bratislava. 97 pp. ISBN 80-88833-14-0.

GRISHINA, L.A. - BARANOVA, T.A. 1990. Vplyv kyslých zrážok na vlastnosti pôd lesného ekosystému južnej tajgy [Effect of acid precipitation on soil properties of southern taiga forest ecosystem]. In Lesné pôdoznalectvo, no. 10, pp. 121-136.

HIRADATE, S. 2004. Speciation of Aluminium in Soil Environments. In Soil Science and Plant Nutrition, vol. 50, no. 3, pp. 303-314.

HORÁK, V. - DOLEJŠKOVÁ, J. - HEJTMÁNKOVÁ, A. 1995. Toxicita hliníku v rostlinách [Aluminium toxicity in plants]. In Rostlinná výroba, vol. 41, no. 5, pp. 239-245.

HUE, N.V. - CRADDOCH G.R. - ADAMS, F. 1986. Effects of organic acids on aluminium toxicity in subsoils. In Soil Science Society of America Journal, vol. 50, no. 1, pp 28-34.

KANIANSKA, R. 2000. Acidifikácia pôd vplyvom kyslých atmosférických polutantov [Soil acidification due to acidic atmospheric pollutants]. PEDO-DISERTATIONES, Bratislava : VÚPOP Bratislava, 96 pp. ISBN 80-85361-73-6.

KOBZA, J. - BARANČÍKOVÁ, G. - ČUMOVÁ, L. DODOK, R. - HRIVŇÁKOVÁ, K. - MAKOVNÍKOVÁ, J. - NÁČIINIAKOVÁ-BEZÁKOVÁ, Z. - PÁLKA, B. - PAVLENDA, P. - STYK, J. - ŠIRÁŇ, M. - TÓTHOVÁ, G. 2009. Monitoring pôd SR. Aktuálny stav a vývoj monitorovaných pôd ako podklad $k$ ich 
ochrane a d'alšiemu využivaniu [Soil monitoring of Slovak republic. Present state and development of monitored soils as the base to their protection and next land use]. Bratislava : VUPOP Bratislava, 200 pp. ISBN 978-80-89128-54-9.

KOLEKTÍV 2011. Jednotné pracovné postupy rozborov pôd [Unified working methods of soil analysis]. Bratislava : VUPOP Bratislava, 124 pp. ISBN 978-8089128-89-1.

KOZÁK, J. - BORŮVKA, L. 1998. Species of Al ions as related to some characteristics of both agricultural and forest soils of the Šumava region. In Rostlinná výroba, vol. 44, no. 9, pp. 419-426.

MAČUHA, P. 1999. Reakcia domácich odrôd pšenice ozimnej na toxické pôsobenie $\mathrm{Al}^{3+}$ katiónov pri nízkom $\mathrm{pH}$ [Reaction of domestic varieties of winter wheat to the toxic $\mathrm{Al}^{3+}$ cations at low pH]. In Pol'nohospodárska výroba a skúšobníctvo, vol. VII, no. 3-4, pp. 25-27.

MAKOVNÍKOVÁ, J. - KANIANSKA, R. 1996a. Zmeny pôdnej reakcie a obsahu aktívneho hliníka vyvolané simuláciou kyslých zrážok [Changes in soil reaction and active aluminium content induced by simulation of acid properties]. In Rostlinná výroba, vol. 42, no. 4, pp.155-159.

MAKOVNÍKOVÁ, J. - KANIANSKA, R. 1996b. Aktívny hliník a jeho súčasný stav v pôdach SR [Actual status of active aluminium in the soils of the Slovak Republic]. In Rostlinná výroba, vol. 42, no. 7, pp. 289-292.

MAKOVNÍKOVÁ, J. 2002. Stav a vývojové trendy aktívneho hliníka $v$ pôdach SR [Actual status and development of active aluminium in the soils of the Slovak Republic]. In Agriculture (Pol'nohospodárstvo), vol. 48 , no. 12 , pp. 619-624.

MAKOVNÍKOVÁ, J. 2005. Vplyv pôdnych parametrov na distribúciu hliníka v pôdach SR [Effect of soil param- eters on distribution of aluminium in soils of the Slovak Republic]. In Agriculture (Pol'nohospodárstvo), vol. 51 , no. 8 , pp. 436-441.

MAKOVNÍKOVÁ, J. - DODOK, R. 2012. Acidifikácia a zasol'ovanie pôd [Soil acidification and salinisation]. In KOBZA, J. - BARANČÍKOVÁ, G. - DODOK, R. HRIVŇÁKOVÁ, K. - MAKOVNÍKOVÁ, J. - STYK, J. - ŠIRÁŇ, M. Monitoring a hodnotenie vlastností pôd SR a potenciálov ich vývoja [Monitoring and evaluation of soil properties SR and their potential development]. Záverečná správa, Bratislava : VUPOP Bratislava, pp.15-43.

MERIÑO-GERGICHEVICH, J. 2010. $\mathrm{Al}^{3+}-\mathrm{Ca}^{2+}$ interaction in plants growing in acid soils: AL-phytotoxicity response to calcareous amendment. In Soil Science and Plant Nutrition, vol. 10, no. 3, pp. 217-243.

MLÁDKOVÁ, L. - BORŮVKA, L. - DRÁBEK, O. 2004. Distribution of aluminium among its mobilizable forms in soils of the Jizera Mountains region. In Plant Soil and Environment, vol. 50, no. 8, pp. 346-351.

MRVIC, V. - JAKOVLJEVIC, M. - STEVANOVIC, D. ČAKMAK, D. 2007. The forms of aluminium in Stagnosols in Serbia. In Plant Soil and Environment, vol. 53, no. 11 , pp. $482-489$.

RINCÓN-ZACHARY, M. 2010. A possible mechanism and sequence of events that lead to the $\mathrm{Al}^{3+}$-induced $\left[\mathrm{Ca}^{2+}\right]_{\text {cyt }}$ transients and inhibition of root growth. In Plant Signaling \& Behavior, vol. 5, no. 7, pp. 881884. Published online 2010 July 1. DOI: 10.4161/ psb.5.7.11973.

IUSS Working Group WRB. 2007. World Reference Base for Soil Resources 2006. World Soil Resources Report No. 103. FAO, Rome. ISBN 9.2-5-105511-4.

Received: August 21, 2013 